\title{
Pemanfaatan Tradisi Lisan Senjang Musi Banyuasin Sumatra Selatan Sebagai Identitas Kultural
}

\author{
Arif Ardiansyah \\ Universitas PGRI Palembang \\ arif acong@yahoo.com
}

\begin{abstract}
This research examines Senjang as the Oral Tradition Musi Banyuasin South Sumatra. This study used qualitative research with the ethnographic approach. The results showed that the oral tradition of Senjang is as media forms of cultural arts that connect parents with young generation or it can be also between the society and government in delivering the aspiration such as the advice, criticism or even the delivery strategy of happiness feeling. Some attempts have been made to preserve, utilize and develop Senjang tradition through schools, galleries and arts tradition festival. Senjang is present in traditional events such as marriage, thanksgiving, and the other which becomes a cultural identity of Musi Banyuasin.
\end{abstract}

Keywords: Oral Tradition, Senjang, Cultural Identity and Musi Banyuasin

\section{Pendahuluan}

Kabupaten Musi Banyuasin memiliki sejumlah ekspresi budaya yang bersifat tradisi lisan. Penelitian Gaffar (1989:13--21) menunjukkan tradisi-tradisi itu antara lain senjang, andai-andai panjang, pantun, mantra, serambah dan nyambai. Media penyampaian yang digunakan dalam tradisi itu adalah bahasa Musi. Dari sejumlah tradisi itu, senjang saat ini yang masih eksis.

Sejumlah usaha dilakukan oleh Pemerintah Daerah Musi Banyuasin untuk mengangkat tradisi senjang ke permukaan adalah dengan menyelenggarakan Festival Randik. Salah satu mata acara pokok dalam festival tersebut adalah lomba senjang tingkat kecamatan se-Kabupaten Musi Banyuasin. Masyarakat juga memiliki andil besar dalam mengangkat kembali tradisi lisan senjang ke permukaan. Dukungan masyarakat Musi Banyuasin terhadap senjang itu dapat dilihat dari seringnya tradisi ini hadir dan ditanggap masyarakat seperti dalam acara perkawinan yang penulis saksikan beberapa waktu lalu.

Dalam perkembangannya, tradisi senjang memiliki beberapa perubahan mendasar yang tidak bisa dielakkan karena manusia sebagai makhluk sosial juga mengalami berbagai perubahan dalam kehidupannya. Tradisi senjang kini hanya dapat dijumpai dan ditampilkan pada acaraacara adat maupun seremonial pemerintahan di Musi Banyuasin yang menjadi satu cerminan atau upaya membangun citra diri atau identitas seseorang yang berasal dari Musi Banyuasin.

Perubahan terjadi pada musik pengiring senjang yang menggunakan alat musik tradisional. Saat ini, alat musik tradisional sudah tidak lagi digunakan. 
Kebanyakan seniman senjang lebih senang menggunakan organ tunggal (keyboard) sebagai pengiring. Selain perubahan musik pendukung, penciptaan senjang juga sudah mulai bergeser. Jika zaman dahulu penutur senjang biasanya menciptakan senjang secara spontan, sehingga isi yang ingin disampaikan disesuaikan dengan suasana yang dihadapinya (Suan,2008:101), sekarang keahlian tukang senjang (tua) seperti itu sudah sangat langka. Tukang senjang biasanya menyiapkan senjang jauh hari sebelum tampil. Bahkan, sering terjadi tukang senjang menuturkan senjang dengan melihat teks yang telah dipersiapkan (terutama tukang senjang muda).

Perubahan lainnya adalah waktu untuk menampilkan kesenian senjang yang dahulu bisa dimainkan pada malam hari, kini senjang sangat jarang ditampilkan pada malam hari terutama pada acara-acara perkawinan karena penampilan senjang pada malam hari itu sudah tergantikan dengan acara musik modern, seperti orgen tunggal. Dari sisi bentuk, senjang juga mengalami perubahan. Kalau dulu ada aturan jika dalam senjang ada tahapan pembukaan, isi dan penutupan, kini tukang senjang tidak lagi patuh pada 'pakem' tersebut, karena dibatasi dengan waktu yang singkat ketika tampil dalam satu acara. Berbagai perubahan tradisi senjang yang terjadi seperti digambarkan di atas ditengarai penyebabnya adalah perkembangan zaman yang ditandai dengan hadirnya peralatan-peralatan elektronik, kemudahan akses, kemajuan ekonomi, pemekaran, hingga kemajuan dalam bidang politik.

Perubahan-perubahan itu menimbulkan sejumlah pertanyaan Bagaimana senjang sebagai identitas Musi Banyuasin dilestarikan, dimanfaatkan dan dikembangkan sebagai identitas budaya?

Penelitian ini bertujuan: pertama untuk mengetahui bagaimana masyarakat Musi Banyuasin melestarikan, memanfaatkan, dan mengembangkan senjang sebagai akibat dari pemekaran wilayah. Kedua, penelitian ini hendak memperlihatan apakah senjang dalam praktiknya dapat berfungsi sebagai sarana ekspresi identitas budaya masyarakat Musi Banyuasin, karena perubahan yang terjadi pascapemekaran tak bisa lepas dari kepentingan politik di Musi Banyuasin.

Komunitas dan kebudayaan Musi Banyuasin tidak banyak mendapat perhatian dari para peneliti, baik lokal maupun internasional. Sejauh yang berhasil penulis lacak, sangat sedikit yang menyinggung tradisi senjang dan Musi Banyuasin. Penelitian tentang tradisi lisan Musi Banyuasin yang pernah dilakukan antara lain, oleh Gaffar dkk. (1989) Struktur Sastra Lisan Musi dan 
Ahmad Bastari Suan, dkk. (2008) Sastra

Tutur Sumatra Selatan: Peran dan Fungsinya dalam Masyarakat Ogan Komering Ilir dan Musi Banyuasin.

Penelitian yang dilakukan Gaffar menjelaskan struktur yang terdapat dalam sastra lisan Musi. Penelitian ini hanya mendata sejumlah cerita rakyat dan menganalisis unsur-unsur yang membangun cerita tersebut. Penelitian yang dilakukan Suan (2008:97-101) menjelaskan sejumlah tradisi lisan di dua kabupaten, yaitu Kabupaten Ogan Komering Ilir (OKI) dan Kabupaten Musi Banyuasin. Penelitian Suan masih mendeskripsikan tradisi lisan di Musi Banyuasin yang masih hidup dan memiliki sejumlah fungsi di dalamnya. Salah satunya adalah seni tutur senjang. Namun, penelitianpenelitian di atas bisa membantu penulis melihat sejumlah tradisi yang ada di Musi Banyuasin. Sedangkan tulisan yang membahas secara khusus dengan obyek penelitian penulis, yaitu senjang ditemukan satu artikel yang ditulis oleh Linny Oktaviani (2008:1-10), "Senjang: Tradisi Lisan yang Masih Eksis di Musi Banyuasin". Secara keseluruhan, penelitian tentang komunitas dan kebudayaan Musi Banyuasin selama ini, seperti tampak pada uraian di atas, cenderung di luar konteks sosial dan budaya yang melingkupinya dan masih belum mendalam.
Sejumlah penelitian kebudayaan yang ada memfokuskan pada pergulatan tradisi dan kesenian di luar Musi Banyuasin terkait dengan tarik menarik kelompok sosial kultural dan penentuan identitas. Disertasi Anoegrajekti (2006) misalnya, membahas gandrung Banyuwangi. Anoegrajekti menguraikan bahwa gandrung dihegemoni oleh tiga kekuatan: pasar, birokrasi, dan agama sehingga kesenian itu mempresentasikan panduan ketiganya dengan dominasi pasar. Dalam konteks seperti itu, identitas menjadi bukan sesuatu yang diciptakan secara politis, melainkan juga sesuatu yang bergerak maju. Disertasi itu juga memperlihatkan kekuatan-kekuatan saling bersaing untuk mendapatkan identitas, yaitu gandrung pasar, gandrung tradisi, dan gandrung agama.

Konsep dan Teori yang Digunakan

Penelitian ini menggunakan model etnografis yang berupaya memahami caracara orang berinteraksi melalui fenomena teramati dalam kehidupan sehari-hari. Lazimnya model ini berusaha menguraikan budaya tertentu secara holistik, yaitu aspek budaya baik spiritual maupun material. Dari sini akan terungkap pandangan hidup dari sudut pandang penduduk setempat. Dengan demikian, akan ditemukan makna tindakan 
budaya suatu komunitas yang dieksperesikan melalui apa saja (Endraswara, 2006: 50-51).

Tradisi lisan menurut Sibarani (2012:123), adalah kegiatan budaya tradisional suatu masyarakat yang diwariskan secara turun-temurun dengan lisan dari satu generasi ke generasi berikutnya, baik tradisi itu berupa susunan kata-kata lisan (verbal) maupun tradisi lain yang bukan lisan (nonverbal). Lalu, Pudentia (2007:27) menyatakan, tradisi lisan adalah wacana yang diucapkan atau disampaikan secara turun-temurun meliputi lisan dan beraksarara, yang semuanya di sampaikan secara lisan.

Sims dan Stephens (2005:19) memberi batasan tradisi lisan adalah hal-hal yang dipelajari secara informal, semacam pengetahuan tentang dunia, diri, komunitas, kepercayaan, budaya, dan tradisi yang terekspresikan melalui pelbagai media antara lain perkataan, musik, pakaian, tindak, tingkah laku, dan benda-benda. Lebih jauh, tradisi sebagai suatu proses (yang dinamis) menciptakan, mengomunikasikan, dan mempertunjukkan pengetahuan. Pudentia (2000:3) menjelaskan bahwa tradisi lisan tidak hanya mencakup cerita rakyat, tekateki, pribahasa, nyanyian rakyat, mite, dan legenda saja, tetapi juga berkaitan dengan sistem kognitif kebudayaan, seperti sejarah hukum, dan pengobatan yang di sampaikan dari mulut ke mulut.

Ong (2013:15) melihat tradisi lisan sebagai sesuatu yang mengalami perubahan seiring perkembangan zaman yang diikuti dengan perubahan sikap dan kebiasaan masyarakat. Ong melihat ada perubahan tradisi lisan pada masa sebelum masyarakat mengenal tulisan yang diistilahkannya sebagai kelisanan primer (primary orality), sedangkan tradisi lisan masa tulisan diistilahkannya sebagai kelisanan sekunder (secondary orality). Antara tradisi lisan primer dan tradisi lisan sekunder memiliki keterkaitan satu dengan yang lainnya. Namun, tradisi lisan primer dapat berdiri sendiri tanpa ada kaitan sama sekali dengan tulisan, sementara tulisan tak pernah ada tanpa kelisanan (Ong, 2013:11). Baik kelisanan primer maupun kelisan skunder memiliki fungsi di dalam khalayaknya.

\section{Finnegan}

(1992:126-127)

mengatakan bahwa tradisi lisan memiliki banyak fungsi di dalam masyarakat. Fungsi yang muncul sangat dipengaruhi oleh siapa pelakunya, untuk siapa tradisi dipertunjukkan, dan seberapa besar keterlibatan partisipan atau penafsir berada di dalam pertunjukan. Artinya suatu pertunjukan tradisi memungkinkan dapat memunculkan beberapa fungsi sekaligus, yakni untuk 1) memperkuat dan menyerang 
otoritas politik, 2) mengukuhkan atau menentang tradisi, 3) untuk menyindir, 4) propaganda, 5) memenuhi kebutuhan hidup, 6) kebanggan diri, 7) ekspresi keindahan dan rasa cinta, 8) mengeluh, 9) mengungkapkan masalah yang tidak boleh diungkapkan, 10) keluar dari kenyataan hidup yang pahit, 11) penemuan jati diri atau identitas, 12) menghibur, 13) mempersatukan dan memisahkan orang. 14) pedoman keagamaan

Berdasarkan pendapat beberapa ahli di atas, fungsi tradisi lisan di masyarakat sangat bergantung pada jenis dan tujuan tradisi lisan yang berlaku. Artinya, setiap tradisi lisan memiliki fungsi yang berbeda dengan tradisi lisan yang lain. Perbedaan fungsi tradisi lisan terjadi karena perubahan dan kemajuan peradapan dan pola pikir masyarakat. Tradisi senjang di Musi Banyuasin masih eksis sampai sekarang walaupun tradisi yang ada saat ini tidak sama dengan tradisi senjang dahulu. Karena pada dasarnya, suatu tradisi akan lentur mengikuti perubahan zaman saat tradisi hidup ditengahtengah masyarakatnya.

Sibarani (2012:14-27) menyatakan bahwa tradisi lisan dapat menjadi kekuatan kultural dan salah satu sumber utama yang penting dalam pembentukan identitas dan peradaban. Tradisi lisan tidak hanya menyampaikan pesan estetis, pragmatis, dan etis, tetapi juga fungsi historis. Berpijak dari pendapat Sibarani tersebut, fungsi-fungsi tradisi lisan dapat diklasifikasikan sebagai fungsi estetis, fungsi pragmatis, fungsi etis, dan fungsi historis (Fatmahwati, 2016:45). Suatu tradisi lisan dikatakan masih lestari bila fungsi-fungsi tersebut masih diperlukan masyarakatnya.

\section{Metode Penelitian}

Objek penelitian yang dikaji dalam tulisan ini adalah tradisi lisan senjang pada Masyarakat Musi Banyuasin di Sumatra Selatan. Metode yang digunakan dalam penelitian ini adalah metode kualitatif dengan pendekatan etnografis. Dalam melakukan penelitian, penulis melakukan wawancara (interview) dengan para informan yang terdiri dari seniman senjang, tokoh masyarakat, masyarakat pemilik tradisi, tokoh adat, dan birokrat. Teknik observasi-partisipasi dan wawancara mendalam merupakan salah satu teknik pengumpulan data utama dalam penelitian ini.

$$
\text { Penulis juga menyaksikan }
$$
pertunjukan senjang di berbagai tempat baik di Sekayu maupun di Palembang pada kurun waktu Februari-September 2014. Setidaknya, penulis sudah menyaksikan sekitar 11 kali pertunjukan senjang, yaitu 7 kali pertunjukan yang dilakukan Yulia Aziz dalam berbagai acara penarikan undian Bank Sumsel Babel sampai acara perkawinan, 
sisanya adalah pertunjukan yang dilakukan Amrullah dan Emawati dan pesenjang lain.

Dalam kurun waktu itu, penulis telah mewancarai 28 orang yang dipilih terkait dengan tradisi lisan senjang: mulai dari seniman senjang, generasi muda pewaris aktif dan pasif, birokrat, pendidik, intelektual Musi Banyuasin, tokoh masyarakat, sampai semua pelaku yang terlibat dalam pertunjukan senjang.

\subsection{Memanfaatkan, dan Mengembangkan Senjang sebagai Identitas Budaya Musi Banyuasin}

Sebuah tradisi bisa bertahan jika masih mempunyai fungsi di dalam masyarakat pendukung tradisi tersebut. Finnegan (1992) menyatakan tradisi lisan memiliki banyak fungsi yang kemunculannya sangat dipengaruhi oleh siapa pelakunya, untuk siapa tradisi dipertunjukkan, dan seberapa besar keterlibatan partisipan dalam pertunjukan. Artinya suatu pertunjukan tradisi memungkinkan dapat memunculkan beberapa fungsi sekaligus.

Pengkajian terhadap fungsi tradisi senjang di Kabupaten Musi Banyuasin bertujuan untuk mengungkapkan peran tradisi dalam kehidupan masyarakat dengan mengacu pada klasifikasi yang sudah dijelaskan dalam bab terdahulu. Sejumlah fungsi yang terdapat di dalam tradisi lisan Senjang sebagai berikut.

Tabel 4.1 Fungsi Tradisi Lisan Senjang

\begin{tabular}{|l|l|l|}
\hline No & Jenis Fungsi & Klasifikasi Fungsi \\
\hline 1 & Fungsi Estetis & Keindahan \\
\hline 2 & Fungsi Pragmatis & Menyindir \\
& & Propaganda \\
& & Alat untuk memprotes \\
& & Mengeluh \\
& & Sumber pengetahuan dan kebijaksanaan \\
& & Alat pengesahan kebudayaan \\
& & Solidaritas kolektif \\
\hline 3 & Etis & Penerangan dan Hiburan \\
\hline 4 & Historis & Alat pendidikan \\
& & Pengontrol,pemaksa berlakunya norma-norma yang ada di masyarakat \\
\hline
\end{tabular}

Pada tabel di atas diketahui bahwa terdapat empat jenis fungsi yang diemban oleh tradisi senjang di dalam kehidupan masyarakat Musi Banyuasin. Pembahasan terhadap fungsi tradisi lisan diuraian di bawah ini. 


\subsection{Fungsi Estetis}

Fungsi estetis tradisi lisan terlihat dari bentuk tradisi ini, dimana tradisi ini terdiri dari sampiran dan isi. Sampiran biasanya berisi tentang kondisi atau suasana yang alam atau sumber daya alam yang ada di Musi Banyuasin, sedang isi adalah sesuatu yang solidaritas kolektif, dan penerangan dan hiburan.

Sebagai alat untuk menyindir, tradisi lisan senjang berfungsi untuk menyindir atau mencela orang atas perbuatannya atau sikapnya di dalam masyarakat. Berikut kutipannya.

\footnotetext{
S.2. (larik ke (51)-56))

- Mamakku Abu ai senang ati

- Boleh menantu baek perangi

- Ulas nunjuk parangi ngenjuk

- Diajak ke dapo takut ngen piok

- Diajak ke ume takut ngen beghuk

- Gulai jeghuk dienjuknye calok

ingin disampaikan. Menurut Tarmizi, uniknya jumlah sampiran dan isi ini tidak sama dengan jumlah larik masing-masing senjang. Artinya, jika sampiran berjumlah enam larik maka isi bisa lebih dari enam karena isi lebih banyak tergantung apa yang ingin disampaikan. Selain itu, pada teks senjang unsur rima, aliterasi, dan asonansi masih mendominasi serta penting seperti puisi-puisi lisan lainnya.
}

\subsection{Fungsi Pragmatik}

Fungsi pragmatik adalah fungsi kepraktisan dan kegunaan suatu tradisi lisan senjang di masyarakat Musi Banyuasin. Dari klasifikasi yang ada fungsi pragmatik Senjang adalah: sebagai alat penyindir, proganda, kritik sosial, mengeluh, sumber pengetahuan, pengesah kebudayaan,
- $\quad$ Paman ku Abu ai Senang hati

- Dapat menantu baik perangai

- Wajah bagus perangai baik

- Diajak ke dapur takut dengan priok

- Diajak ke kebun takut dengan beruk

- Gulai tempoyak diberinya terasi

$\bullet$ 
Banyuasin. Propaganda ini sangat terlihat pada teks-teks senjang yang ditampilkan pada lomba-lomba senjang yang digagas oleh Pemkab. Berikut kutipannya.

- $\quad$ Pergi ke pasar meli mangga Pergi ke pasar membeli mangga

- Jangan lali meli belewah Jangan lupa membeli belewah

- $\quad$ Belike pule buah markisa Beli pula buah markisa

- Buah buat es buah Buah buat es buah

- Ubat haus dengen dahaga Obat haus melepas dahaga

- Kami dayi kabupaten Muba Kami dari kabupaten Muba

- Kota neman dapat adipura Kota sering dapat Adipura

- Dengen program mengena Dengan program mengena

- I milyar satu desa I Milyar satu desa

- Dijamin bersih dan sejahtera Dijamin bersih dan sejahtera

Propaganda ini terlihat pada teks senjang yang dibawakan oleh Ema dan Manto pada acara Festival Sriwijaya di Palembang 2014. Penyampain teks senjang pada acara yang dihadiri oleh seluruh kabupaten di Sumatra Selatan ini membuktikan bahwa kabupaten Musi Banyuasin ingin dianggap berbeda dengan kabupaten dan kota lainnya di Sumatra Selatan. Selain itu, dalam teks senjang itu, Ema dan Manto juga menyinggung soal kemajuan yang sudah dicapai oleh Musi Banyuasin.

Program Satu Milyar Satu Desa merupakan program yang diklaim oleh Kabupaten Musi Banyuasin sebagai satu- satunya program di Provinsi Sumatra Selatan. Berikut salah satu kutipan senjang yang berisi tentang salah satu program pasangan Pahri Azhari dan Beni Herneadi, yang dibawakan pada Festival Randik 2013 oleh wakil Kecamatan Sanga Desa:

\begin{tabular}{|c|c|}
\hline Bahasa Daerah Musi & Bahasa Indonesia \\
\hline 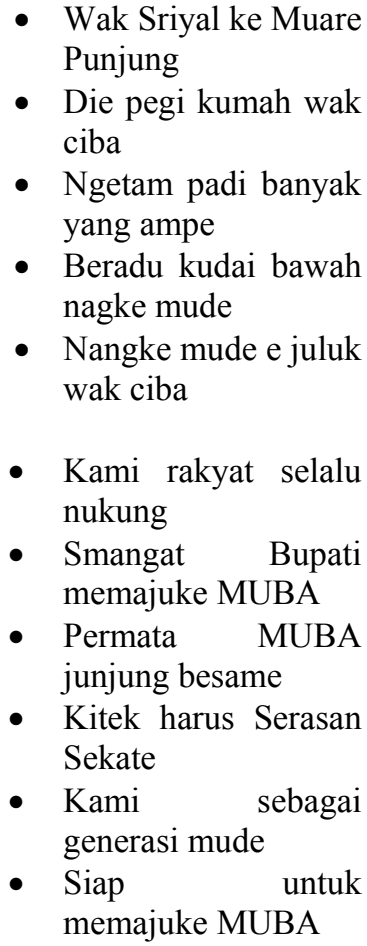 & $\begin{array}{l}\text { - Wak Sriyal ke Muara } \\
\text { Punjung } \\
\text { - Dia pergi ke rumah } \\
\text { Wak Ciba } \\
\text { - Ngetam padi banyak } \\
\text { ampas } \\
\text { - Berteduh di bawah } \\
\text { nangka muda } \\
\text { - Nangka muda di } \\
\text { ambil Wak Ciba } \\
\text { - Kami rakyat selalu } \\
\text { mendukung } \\
\text { - Semangat Bupati } \\
\text { memajukan MUBA } \\
\text { - Permata MUBA } \\
\text { junjungan bersama } \\
\text { - Kita harus } \\
\text { - Kerundingan sekata } \\
\text { Kami sebagai generasi } \\
\text { muda a untuk } \\
\text { - Siap memajukan MUBA }\end{array}$ \\
\hline
\end{tabular}

Teks senjang di atas berisi program yang sedang dijalankan oleh pemerintahan periode Pahri Azhari dan Beni Herneadi (2012-2017), yaitu Permata Muba 2017. Program ini diklaim merupakan satu-satunya program pertama dan menjadi pembeda dengan kabupaten lain yang ada di Sumatra Selatan. Mereka menyebutnya Pelopor Pembangunan Desa.

Fungsi senjang untuk menyampaikan kritik sosil sudah menjadi hal yang lumrah di 
Musi Banyuasin. Para pejabat juga memaklumi jika ada kritikan dari tukang senjang saat mereka menghadiri acara-acara yang menampilkan senjang. Selama ini, juga belum pernah terdengar tukang senjang dihukum karena mengkritik pemerintah karena format penyampaiannya selalu didahului dengan permohonan izin dan maaf, dan diakhiri pula dengan permohonan pamit dan maaf. Melalui iringan musik dan tari yang dilakukan tukang senjang, kritik yang disampaikan oleh tukang senjang menjadi enak didengar, dan tidak membuat pihak yang dikontrol atau dikritik tersinggung. Senjang mengkritik tetapi tidak menyakiti, mengontrol tetapi tidak menghujat pihak yang dikritiknya. Lagi pula, semua sepakat jika yang disampaikan tukang senjang biasanya terkait dengan kondisi masyarakat saat itu.

Kehidupan manusia yang penuh dengan problematika kadang-kadang tidak dapat disampaikan secara langsung, dia hanya bisa disampaikan melalui tradisi ini. Keluhan harga karet yang rendah, jalan rusak, sampai kehidupan yang susah tergambar di dalam teks-teks senjang yang dilantunkan oleh tukang senjang. Hal itu menunjukkan bahwa senjang berfungsi untuk menyampaikan keluhan masyarakat.

Sebagai sumber pengetahun dan kebijaksanaan, senjang tidak hanya menggambarkan kondisi geografis, flora, dan fauna yang ada di kabupaten tersebut tetapi juga menjelaskan berbagai penguasan teknologi membuat perangkap ikan, seperti membuat rawai dan bubu. Selain itu, senjang juga menggambarkan perkampungan yang mengikuti alur sungai dan bentuk-bentuk rumah yang selalu menghadap ke sungai yang disebut rumah rakit yang merupakan pengetahuan lokal yang dimiliki oleh masyarakat Musi Banyuasin. Berikut kutipan teks senjang yang dimaksud peneliti.

S.10.I (baris ke (72)-(77))

- Pegi ke sungai ngunde tanggok Pergi ke sungai membawa tangguk

- Nak nanggok ikan bojok Mau menangkap ikan bujuk (gabus)

- Ikan bojok digulai jeghuk Ikan gabus digulai tempoyak

- Sambal kemang dienjuk calok Sambal buah kemang diberi terasi

- Ulamnye petai dingen karupuk Lalapnya petai dengan kerupuk

- Beanye ubi buat pelicuk Buah ubi buat pepes

S.8.I (baris ke (1)-(8))

- Kajang kedup beisi serandang Keranjang kedup berisi (ikan) serandang

- Boleh kene tajur di paye Dapat najur di rawa

- Baung kene pancing tesangkut Baung kena pancing tersangkut

- Ikan betutu kanti bantalu Ikan betutu bersama bantalu

- Ikan ruan buat pindang Ikan gabus dibuat pindang

- Nyunjung tampa beisi kopi mengangkat tampa berisi kopi

- Ka panungkal meli kentang Ke Penungkal membeli kentang

- Meli Bunge serta daun Membeli Bunga serta daun

Berdasarkan teks-teks senjang di atas, terdapat adanya penggunaan kata-kata yang 
terkait dengan sungai, seperti ruan dan bojok yang merupakan nama-nama ikan. Selain itu, terdapat pula adanya kata-kata rawai, kajang kedup, pancing, dan tajur yang merupakan alat untuk menangkap ikan. Alat-alat tersebut masih dipakai oleh masyarakat Musi Banyuasin untuk menangkap ikan sampai sekarang. Jenis-jenis ikan yang disebutkan tadi masih banyak terdapat di sungai-sungai yang mengalir di daerah Musi Banyuasin.

Menurut Haris (2004:254), kajang kedup adalah alat berupa keranjang tetapi memakai tutup yang diberi injap supaya ikan yang dimasukkan ke dalam keranjang tidak dapat keluar. Injap kajang kedup tersebut dapat dibuka untuk mengeluarkan ikan dan dapat ditutup lagi.

Dari teks-teks senjang itu masyarakat Musi Banyuasin melakukan transformasi pengetahuan daerah dengan cara disebutkan di dalam teks-teks senjang. Pengetahuan itu akan abadi jika terus menerus dilantunkan serta disebutkan dalam setiap penampilan senjang. Penyebutan nama-nama sungai memberi pengetahuan bahwa daerah dikelilingi sungai menjadikan sungai sebagai salah satu sumber penghidupan mansyarakatnya. Tradisi ini berbertahan karena masih adanya fungsi pengetahuan yang ada di dalam teks-teks senjang, salah satunya adalah pengetahuan tentang geografi setempat.
Sejumlah teks senjang yang dikumpulkan dari berbagai penampilan Amrullah, Yulia, dan peserta festival senjang lainnya, dapat disimpulkan bahwa kesenian ini berfungsi sebagai alat pengesahan kebudayaan yang merupakan milik Kabupaten Musi Banyuasin. Teks itu menyebutkan dengan jelas jika kesenian ini hanya ada di daerah Musi Banyuasin.

Tradisi senjang pada masyarakat Musi Banyuasin dipakai sebagai alat untuk pengesahan kebudayaan mereka. Pengesahan ini di dukung oleh pemerintah dalam hal ini Kementerian Pendidikan dan Kebudayaan dengan menetapkan senjang sebagai warisan budaya tak benda Musi Banyuasin pada 2015.

Dengan adanya penetapan ini makin membuktikan bahwa fungsi senjang sebagai alat penegas kebudayaan juga didukung oleh pihak-pihak di luar komunitasnya. Penetapan ini berdasarkan kondisi tradisi tersebut yang masih eksis, memiliki maestro, dan memiliki pendukung. Selain amanat UUD 1945 pasal 32, penetapan ini juga bertujuan agar kepala daerah di tingkat provinsi dan kabupaten, juga para pemangku kepentingan dan masyarakat luas dapat turut melakukan pelestarian, dengan menjaga, melindungi, dan mengelola sebaik mungkin kekayaan budaya tersebut. 
Salah satu fungsi senjang adalah membangun solidaritas kolektif masyarakat Musi Banyuasin. Melalui senjang, masyarakat Musi Banyuasin menjadi dekat satu dengan yang lain. Hal ini terbukti saat senjang tampil di kota Palembang yang direspon dengan sangat antusias oleh pendengarnya. Salah satu sebabnya karena penonton sebagian besar berasal dari masyarakat Musi Banyuasin yang merantau di kota Palembang.

Sebagai tontonan atau hiburan, senjang tidak ada kaitannya dengan upacara ritual. Pertunjukan ini diselenggarakan benar-benar hanya untuk hiburan, yaitu misalnya tampil pada peringatan kelahiran, resepsi pernikahan, dan lain-lain. Tujuannya jelas, memberi pengalaman estetis kepada penonton.

$$
\text { Syair senjang bisa menghibur }
$$
penonton dengan kata-kata jenaka. Fungsi hiburan ini juga dapat dirasakan ketika senjang akan ditampilkan dengan musik pengiring. Penampilan senjang selalu diiringi oleh musik yang dinamis. Musik dan penuturan senjang tampil secara bergantian. Sebelum bagian pembuka, ada musik yang mengiringinya. Antara bagian pembuka dan bagian isi juga diselingi musik. Antara bagian isi dan bagian penutup pun diselingi musik. Pada bagian akhir, musik akan muncul lagi. Walaupun irama musiknya hanya diulang-ulang, penonton akan merasa terhibur dengan respon menggelengkan kepala mengikuti syair atau bertepuk tangan, atau hanya diam meresapi makna senjang.

\subsection{Fungsi Etis}

Fungsi etis merupakan fungsi yang berhubungan dengan etika dan norma yang berlaku di dalam masyarakat. Fungsi etis tradisi senjang meliputi: sebagai sarana menyampaikan nasihat atau pendidikan dan pengontrol atau pemaksa norma-norma yang ada di masyarakat Musi Banyuasin.

Senjang dipakai untuk menyampaikan nasihat (didaktis) baik kepada pengantin, anak-anak, maupun kepada remaja. Biasanya senjang dituturkan pada saat pesta perkawinan dan khitanan. Saat itu, semua keluarga baik tua maupun muda, dewasa maupun anak-anak berkumpul. Dengan demikian, semua usia dapat mengikuti penuturan senjang. Pesan moral yang dituturkan oleh tukang senjang dengan bernyanyi sambil menari cukup menghibur dan tidak terkesan menggurui.

Umumnya, bait-bait senjang memuat nilai-nilai atau pesan-pesan moral yang sering dilantunkan oleh tukang senjang terkait hubungan dengan keluarga besar, hubungan dengan ipar, atau mertua. Bait-bait itu sering ditujukan kepada pengantin 
perempuan agar dapat menjaga dan membawa diri.

Tokoh masyarakat Musi Banyuasin Yusman Haris, dalam wawancara dengan penulis, mengatakan, adat perkawinan Musi Banyuasin selalu diartikan penggabungan dua keluarga besar. Jadi, pernikahan bukan antara si bujang dan si gadis semata, tetapi seluruh keluarga harus terlibat. Dalam perkawinan masyarakat Musi Banyuasin, anak laki-laki yang baru menikah biasanya tidak langsung pergi dari rumah orangtuannya. Dia akan tinggal beberapa lama dengan ibu, bapak, dan saudarasaudaranya sebelum memiliki rumah sendiri (sekarang sudah jarang terjadi sebab pasangan muda saat ini sebelum menikah sudah memiliki rumah sendiri, minimal kontrak). Oleh karena itu, ada pesan tukang senjang kepada pengantin perempuan untuk dapat menyesuaikan diri dengan keluarga suami.

\subsection{Fungsi Historis}

Tradisi senjang adalah dokumen dalam bentuk sumber-sumber lisan yang dapat dijadikan bahan sejarah masyarakat Musi Banyuasin. Teks-teks senjang yang menyebutkan kondisi alam yang didominasi oleh sungai membuat daerah Musi Banyuasin menjadi daerah yang terbuka dari budaya lainnya. Namun sampai saat ini tradisi senjang masih tetap eksis dan dibutuhkan oleh masyarakat. Artinya, sikap toleransi dan saling menghormati dalam kehidupan seharihari menjadi ciri atau identitas masyarakat Musi Banyuasin. Selain itu, tradisi senjang yang diwariskan secara turun menurun, dari generasi ke generasi berikutnya dan dapat bertahan sampai saat ini membuktikan bahwa tradisi ini masih berfungsi.

Penggunaan bahasa Musi sebagai media penyampaian juga menjadi bukti bahwa fungsi pembentukan identitas masyarakat Musi Banyuasin sudah berjalan sedemikian lama dan berkelanjutan. Sejumlah teks senjang yang menyebutkan sejumlah tokoh legenda yang ada di Musi Banyuasin makin menegaskan bahwa senjang berfungsi sebagai alat historis dalam membentuk identitas masyarakat Musi Banyuasin. Berikut kutipannya.

- Gulai lemak si ikan salai

- Gulai santan si ikan

- Galaian ngen tehung oi tehung mude

- Itu hoby puyang kite besame

- Puyang Depati itu namenye

- Di kampung empat tempat makamnye

- $\quad$ Terime kasih engen anak belai

- $\quad$ Salai terong oi terong muda

- Itu lah hobby nenek moyang kita bersama

- Nenek moyang itu Depati namanya

- Makamnya di Kampung Empat

- Same dolor jiron tetangge

- Juge kepade betine dapo

- La ilang arai ninggalke gawe

- $\quad$ Mutung gale ai bulu rume

- Merojong bangian duduk bedue
- Terima kasih dengan panitia perkawinan

- Sama saudara dan jiron tetangga

- Juga kepada perempuan di dapur

- Sudah hilang hari meninggal kerjaan

- Hangus semua ai bulu halus

- Merestui pengantin duduk berdua 
Salah satu nama tokoh legenda yang berkontribusi dalam perjalanan sejarah kabupaten Musi Banyuasin adalah Puyang Depati. Berdasarkan sumber-sumber lisan, dikatakan bahwa Puyang Depati adalah orang yang pertama diangkat oleh Sultan Palembang menjadi penguasa (Kadipatenan) untuk wilayah Musi Ilir, yang kedudukannya di kota Sekayu, dan beliaulah yang asal mulanya membuat nama SAKAYU atau Sekayu pada sekitar 1745. Nama aslinya adalah Sahmad bin Sahaji bin Aji Ginggang Bin Mujmal Bin Sidun bin Sawir bin Kitri bin Samaun bin Huzon Bin Hubbas dari Gujarat India.

Saat ini, makam Sahmad bin Tahaji (Puyang Depati) terletak di dekat masjid Agung Kelurahan Soak Baru Sekayu, tepatnya di lingkungan IV Kelurahan Soak Baru Kecamatan Sekayu, di Jalan Merdeka. Kuburan Puyang dirawat dengan baik, dipasang atap seng, berdinding papan, dan berlantai keramik. Menurut warga, Puyang Depati sering memperingatkan anak cucunya dengan memberi tanda-tanda seperti di lingkungan IV Kelurahan Soak Baru, bila muncul seekor buaya di Sungai Musi, itu tanda akan adanya bahaya bagi masyarakat sekitar khususnya, masyarakat Muba pada umumnya.

\section{Kesimpulan}

\subsection{Simpulan}

Ada empat fungsi yang diemban oleh tradisi senjang dalam kehidupan masyarakat Musi Banyuasin. Fungsi estetis atau keindahan dapat dilihat dari bentuk yang ada pada senjang yang terdiri dari sampiran dan isi. Tradisi senjang sebagai wadah bagi seniman senjang mengembangkan ide seni dalam bentuk sampiran dan isi yang syarat mengandung nilai-nilai keindahan. Fungsi pragmatik terlihat pada pemanfaatkan tradisi senjang yang dijadikan: 1) sebagai alat untuk menyindir, 2) sebagai alat untuk propaganda, 3) sebagai alat untuk protes atau kritik sosial, 4) mengeluh, 5) sumber pengetahuan dan kebijaksanaan, 6) alat pengesahan kebudayaan, 7) solidaritas kolektif, dan 8) penerangan dan hiburan. Sementara fungsi pragmatis tradisi sebagai pedoman agama, pemenuhan kebutuhan hidup, sebagai superior seseorang, dan sebagai pencari dana sosial tidak terdapat di dalam tradisi senjang Musi Banyuasin.

Fungsi etis terlihat dari masyarakat yang memanfaatkan tradisi senjang: 1) sebagai alat pendidikan, 2) pemaksaan berlakunya norma-norma yang berlaku di masyarakat. Senjang juga berfungsi historis, yaitu sebagai pembentukan identitas dan pelestari sistem budaya masyarakat di Kabupaten Musi Banyuasin. Bertahannya 
tradisi senjang di Kabupaten Musi Banyuasin sampai saat ini karena tradisi ini masih dapat mengemban fungsi-fungsi dan diwariskan antargenerasi.

\subsection{Saran}

Tradisi lisan senjang merupakan bentuk ekspresi masyarakat Musi Banyuasin yang mengandung nilai-nilai luhur masyarakat setempat yang menjadi identitas lokal. Untuk mempertahankan salah satu budaya yang masih eksis di Musi Banyuasin, diharapkan masyarakat Musi Banyuasin memahami bahwa tradisi senjang merupakan kekayaan yang menjadi ciri khas daerah tersebut dan dapat menjadi sumber deposit kekayaan yang tidak habishabisnya. Masyarakat Musi Banyuasin harus memahami bahwa tradisi senjang yang memuat kearifan lokal bermanfaat bagi mereka sebagai bahan ajar kehidupan. Selain itu, masyarakat harus diyakinkan bahwa hilangnya sebuah tradisi yang merupakan identitas lokal akan menggerus karakter masyarakat Musi Banyuasin. Oleh sebab itu, perlu keterlibatan secara penuh dalam upaya melestarikan tradisi senjang melalui berbagai pertunjukan senjang di luar acara-acara adat dan kegiatan-kegiatan yang melibatkan masyarakat luas.

Sementara, untuk pemerintah daerah diharapkan juga mendukung semua kegiatan pelestarian melalui pembuatan peraturan daerah untuk memperkuat upaya-upaya penguatan yang dilakukan masyarakat, menyediakan tenaga-tenaga ahli dan berpengalaman untuk pengembangan tradisi lisan senjang.

Penelitian ini hanya membahas salah satu bagian dari tradisi lisan yang ada di Musi Banyuasin karena terbatasnya waktu, tenaga, dan biaya. Setidaknya, peneliti melihat masih banyak yang bisa diteliti selain tradisi lisan senjang ini, antara lain adalah pendokumentasian bahasa Musi, fonologi bahasa Musi, dan kajian-kajian dari berbagai perspektif ilmu lainnya, seperti ilmu hukum. Sebab, banyak aturan-aturan adat di dalam Undang-undang Simbur Cahaya yang masih relevan dengan hukum yang berlaku saat ini.

\section{Daftar Referensi}

Aliana, Zainul Arifin dkk. 1996 Unsur Kekerabatan dalam Tutur Sastra Nusantara di Sumatera Selatan. Jakarta: Pusat Pembinaan dan Pengembangan Bahasa, Departemen Pendidikan dan Kebudayaan.

Danandjaja, James. 2007. Folklor Indonesia: Ilmu Gosip, dongeng, dan lain-lain. Jakarta: Grafiti.

Endraswara, Suwardi.2006. Metodologi Penelitian Kebudayaan. Yogyakarta: Gajah Mada University Press. 
Fatmahwati, 2016. Tradisi Lisan Besesombau Melayu Tapung (Struktur, Fungsi, Revitalisasi, Pemanfaatan Bagi Masyarakat, dan Implikasi Pembelajaran Bahasa). Disertasi Tidak Diterbitkan. Bandung: Universitas Pendidikan Indonesia.

Finnegan, Ruth. 1992. Oral Traditions and The Verbal Art. A Guide to Research Practices. New York. Routledge

Gaffar, Zainal Abidin, dkk. 1989. Struktur Sastra Lisan Musi. Jakarta: Departemen Pendidikan dan Kebudayaan.

Gani, Zainal Abidin. 1985. Struktur Bahasa Musi. Jakarta: Pusat Pembinaan dan Pengembangan Bahasa, Departemen Pendidikan dan Kebudayaan.

Geertz, Clifford. 1974. "Deep Play: Notes on The Balinesse Cockfight" in The Interpretation of Cultures: Selected Essays. London. Hutchison \&CO Publisher LTD.

Haris, Yusman. 2004. Bumi Serasan Sekate dan Penduduknya. Pemerintah Kabupaten Musi Banyuasin. Sekayu.

Hastanto, Sri. 2010. "Budaya Identitas Bangsa, Identitas Budaya Bangsa", dalam (ed) Kenedi Nurhan. Industri Budaya, Budaya Industri. Kongres Kebudayaan Indonesia 2008. Jakarta: Kementerian Kebudayaan dan Pariwisat Republik Indonesia.

Ikram, Achadiati. 1964. "Pantun dan Wangsalan". Majalah Ilmu-ilmu Sastra Indonesia.

Irwanto, Dedi. dkk .2010. Iliran dan Uluan : Dikotomi Dan Dinamika Dalam Sejarah Kultural Palembang. Yogyakarta: Eja Publisher.

Lan, Thung Ju.2011. Nasionalisme dan Ketahanan Budaya di Indonesia: Sebuah Tantangan. Jakarta: LIPI dan Yayasan Obor Indonesia.

Li, Tania Murai (2012) The Will to Improve "Perencanaan, Kekuasaan, dan Pembangunan di Indonesia. Jakarta: Margin Kiri.

Lord, Albery B. 2000. The Singer of Tales. Cambridge, Massachusetts London: Harvard University Press.
Oktavianny, Linny. 2008. "Senjang: Tradisi Lisan yang Masih Eksis di Musi Banyuasin”. Pusat Penelitian Balai Bahasa Palembang.

Ong, Walter J. 1989. Orality and Literacy: The Technologizing of the Word. London and New York: Routlegde.

PaEni, Muklis. 2011. "Melihat Kembali Nasionalisme Indonesia dalam Konteks Masyarakat Plural Melalui Perspektif Sejarah" dalam Thun Ju Lan. Nasionalisme Ketahanan Budaya di Indonesia: Sebuah Tantangan. Jakarta: Yayasan Obor Indonesia.

Pudentia, MPSS. 2000. Mak Yong: Hakikat dan Proses Penciptaan Kelisanan. Disertasi Pascasarjana Universitas Indonesia: Jakarta

2008. Metodologi Kajian Tradisi Lisan . Jakarta: Asosiasi Tradisi Lisan.

2007. Hakikat Kelisanan dalam Tradisi Melayu Mak Yong. Depok: Fakultas Ilmu Budaya (FIB) UI.

Pradopo, Rachmat Djoko. 1995. Pengkajian Puisi: Analisis Strata Norma dab Analisis Struktural dan Semiotika. Yogyakarta: Gadjah Mada University Press.

Sibarani, Robert. 2012. Kearifan Lokal: Hakikat, Peran, dan Metode Tradisi Lisan. Jakarta: Asosiasi Tradisi Lisan.

Sims, Martha C., Martine Stephens. 2005. Living Folklore. An Introduction to Study of People and Their Traditions. Utah: Utahh State University Press.

Spradley, James P. 2007. Metode Etnografi. Yogyakarta: Tiara Wacana.

Suan, Ahmad Bastari, dkk. 2008. Sastra Tutur Sumatra Selatan: Peran dan Fungsinya dalam Masyarakat. Palembang. Dinas Pendidikan Provinsi Sumsel.

Sweeney, Amin. 1987. A. Full Hearing Orality and Lyteracy in the Malay Word. London: University Of California Press.

Teeuw, A. 1994. Indonesia antara Kelisanan dan Keberaksaraan. Jakarta: Pustaka Jaya. 
Tol, Roger dan Pudentia (1995). "Tradisi Lisan Nusantara: Oral Tradisions From The Indonesia Achipelago A ThreeDirectional Approach" Junal ATL edisi Pedana No.1/Maret 1995. Jakarta.

Vansina, Jan. 1973. Oral Tradition. Pinguin University Books.

Vansina, Jan. 1985. Oral Tradition As History. The University of Winconsis Press. 